DOI: https://doi.org/10.31392/NZ-npu-143.2019.07

УДК 378. 091.33-027.22:811.111

Вітченко А. Ю.

\title{
ВИКОРИСТАННЯ КЕЙС-ТЕХНОЛОГІЇ НА ПРАКТИЧНИХ ЗАНЯТТЯХ 3 АНГЛІЙСЬКОЇ МОВИ У ЗАКЛАДАХ ВИЩОЇ ОСВІТИ
}

Серед основних методичних проблем викладання англійської мови у закладах вищої освіти провідного значення набуває використання інтерактивних технологій, щзо забезпечують реалізацію комунікативного підходу, сприяють формуванню іншомовної компетентності. До найефективніших інтерактивних технологій навчання належить кейс-технологія, що дає змогу активізувати прочес іншомовної комунікачії, проблематизувати навчальний матеріал, сформувати у студентів досвід практичного використання набутих знань, умінь і навичок під час вивчення іноземної мови.

У статті теоретично обтрунтовано та практично перевірено ефективність використання кейс-технологї̈ на практичних заняттях з англійської мови у закладах вищої освіти. Розкрито сутність кейс-технологї, яка полягає у вивченні конкретних випадків (ситуацій, історій, тексти яких називаються “кейсами”) із життя та професійної діяльності для спільного аналізу, обговорення та вироблення рішень. Проаналізовано переваги використання кейсів на практичних заняттях з англійської мови, розглянуто структурні елементи кейсу. Виокремлено основні етапи впровадження кейс-технології, наведено приклад використання кейс-технологї̈ на практичних заняттях з англійської мови у закладах вищої освіти.

Доведено, щуо використання кейс-технології дає змогу актуалізувати лексику у прочесі аналізу й обговорення пропонованих проблемних ситуацій, відпраџьовувати практичні вміння будувати монологічні висловлювання, брати участь у діалогах і навчальних дискусіях за темою кейсу, підвищувати інтерес до вивчення іноземної мови шляхом проблематизачії навчального матеріалу.

Ключові слова: кейс, кейс-технологія, структурні елементи кейсу, основні етапи впровадження кейс-технології, практичні заняття з англійської мови, заклади вищої освіти.

Серед основних методичних проблем викладання англійської мови у закладах вищої освіти провідного значення набуває використання інтерактивних технологій, що забезпечують реалізацію комунікативного підходу, сприяють формуванню іншомовної компетентності. До найефективніших інтерактивних технологій навчання належить кейс-технологія, що дає змогу активізувати процес іншомовної комунікації, проблематизувати навчальний матеріал, сформувати у студентів досвід практичного використання набутих знань, умінь і навичок під час вивчення іноземної мови.

Теоретичні основи порушеної проблеми набули висвітлення у працях сучасних дослідників А. О. Вітченка [1], Н. М. Заячківської, О.І.Пометун і Л. В. Пироженко [2], Г. П. П'ятакової, С. О. Сисоєвої [3] та ін.

Mema cmammi - теоретично обґрунтувати та практично перевірити ефрективність використання кейс-технології на практичних заняттях з англійської мови у закладах вищої освіти.

Вперше кейс був застосований у 1870 р. викладачами школи права 
Гарвардського університету (Harvard Law School), далі він набув поширення у 20-х pp. XX cт. при викладанні управлінських дисциплін у Гарвардській бізнес-школі (Harvard Business School). На сучасному етапі у закладах вищої освіти Великобританії та США кейс-технологія $\epsilon$ однією 3 найпопулярніших інтерактивних технологій навчання.

Сутність кейс-технології сучасні дослідники вбачають у вивченні конкретних випадків (ситуацій, історій, тексти яких називаються "кейсами") із життя та професійної діяльності для спільного аналізу, обговорення та вироблення рішень $[1$, c. 219]. Серед беззаперечних переваг кейс-технології називають те, що кейс одночасно не тільки відображає практичну проблему, але й актуалізує певний комплекс знань, який необхідно засвоїти під час їі вирішення; він вдало поєднує навчальні та виховні завдання, що $€$ важливою умовою реалізації освітньовиховної мети.

Традиційно у структурі кейсу виділяють нормативні та факультативні елементи. До нормативних структурних елементів відносять ситуацію (випадок, проблему, історію) з реального життя або професійної діяльності, а також запитання і завдання для роботи з кейсом. Факультативними елементами вважаються контекст ситуації (хронологічний, історичний, топологічний, особистісний тощо), Авторський коментар до неї, перелік рекомендованих джерел і додатки (таблиці, схеми, графіки, діаграми, документація, карти, відео-, аудіозаписи тощо) [1, с. 220].

Впровадження кейс-технології на заняття 3 англійської мови має відбуватися у три етапи:

1. Підготовчий (самостійна робота студентів над кейсом).

2. Основний (фронтальне обговорення кейсу під час практичного заняття).

3. Заключний (підбиття підсумків).

Наведемо приклад використання кейс-технології на практичних заняттях 3 англійської мови у закладах вищої освіти. За темою заняття "Love and Romance" (модуль I "Family") з дисципліни "Практичний курс англійської мови" на основі інернет-джерел [10; 6; 7; 8; 9; 5; 15; 16] розробили кейс "Love or Duty, that is a question...".

Завдання заняття з використанням цього кейсу:

- поглибити лексичний запас з теми заняття "Love and Romance";

- розвинути вміння використовувати нову лексику у процесі монологічного i діалогічного спілкування;

- удосконалити вміння висловлювати власні погляди іноземною мовою;

- удосконалити граматичні навички застосування Past Tenses та Conditional Sentences в нових ситуаціях спілкування;

- розвивати вміння 3 аудіювання, навчити студентів виокремлювати 3 мовленнєвого потоку необхідну інформацію;

- розвивати вміння писати есе або невеликі за обсягом твори;

- створювати позитивну мотивацію до вивчення англійської мови.

Розроблений "живий" кейс "Love or Duty, that is a question..." складається 3 таких структурних компонентів:

1. Ситуація $[10 ; 6 ; 7 ; 8 ; 9 ; 5 ; 15 ; 16]$.

2. Завдання для опрацювання нової лексики. 
3. Система запитань і завдань для роботи з "тілом" кейсу.

4. Список рекомендованої для опрацювання літератури $[10 ; 6 ; 7 ; 8 ; 9 ; 5 ; 15$; $16 ; 14]$.

5. Додатки (аудіофрагмент King Edward VIII abdication speech 1936 [11], відеофрагмент з фильму “The King's Speech", культурологічний матеріал [14; 8] тощо).

На підготовчому етапі студенти отримують від викладача кейс за тиждень перед проведенням запланованого практичного заняття. Вони самостійно опрацьовують “тіло кейсу" (ситуацію), вивчають допоміжні матеріали, рекомендовані джерела, виконують завдання для опанування нової лексики.

КЕЙС "Love or Duty, that is a question..."

King Edward VIII did something that monarchs do not have the luxury of doing he fell in love. King Edward was in love with Mrs. Wallis Simpson, not only an American, but also a married woman already once divorced. However, in order to marry the woman he loved, King Edward was willing to give up the British throne - and he did, on December 10, 1936.

To some, this was the love story of the century. To others, it was a scandal that threatened to weaken the monarchy.

Prince Edward Growing Up. King Edward VIII was born Edward Albert Christian George Andrew Patrick David on June 23, 1894 to the Duke and Duchess of York (the future King George $V$ and Queen Mary). His brother Albert was born a year and a half later, soon followed by a sister, Mary, in April 1897. Three more brothers followed: Harry in 1900, George in 1902, and John in 1905 (died at age 14 from epilepsy).

Though his parents surely loved Edward, he thought of them as cold and distant. Edward's father was very strict which caused Edward to fear every call to his father's library, since it usually meant punishment.

In May 1907, Edward, only 12 years old, was shipped off to the Naval College at Osborne. He was at first teased because of his royal identity, but soon garnered acceptance because of his attempt to be treated like any other cadet.

After Osborne, Edward continued on to Dartmouth in May 1909. Though Dartmouth was also strict, Edward's stay there was less harsh.

During the night on May 6, 1910, King Edward VII, Edward's grandfather who had been outwardly loving to Edward, passed away. Thus, Edward's father became king and Edward became the heir to the throne.

In 1911, Edward became the twentieth Prince of Wales. Besides having to learn some Welsh phrases, Edward was to wear a particular costume for the ceremony.

"When a tailor appeared to measure me for a fantastic costume . . of white satin breeches and a mantle and surcoat of purple velvet edged with ermine, I decided things had gone too far. . . . What would my Navy friends say if they saw me in this preposterous rig ?" [15, c. 29].

Though it is surely a natural feeling of teenagers to want to fit in, this feeling continued to grow in the prince. Prince Edward began to deplore being set on a pedestal or worshipped - anything that treated him as a "person requiring homage." [15, c. 30].

As Prince Edward later wrote in his memoirs:

"And if my association with the village boys at Sandringham and the cadets of the 
Naval Colleges had done anything for me, it was to make me desperately anxious to be treated exactly like any other boy of my age." [15, c. 30].

World War I. In August 1914, when Europe became embroiled in World War I, Prince Edward asked for a commission.

The request was granted and Edward was soon posted to the $1^{\text {st }}$ Battalion of the Grenadier Guards. The prince, however, was soon to learn that he was not going to be sent to battle.

Prince Edward, extremely disappointed, went to argue his case with Lord Kitchener, the Secretary of State for War. In his argument, Prince Edward told Kitchener that he had four younger brothers who could become heir to the throne if he were killed in battle.

While the prince had given a good argument, Kitchener stated that it was not Edward being killed that prevented him from being sent into battle, but rather, the possibility of the enemy taking the prince as prisoner.

Though posted far from any battle (he was given a position with Commander-inChief of the British Expeditionary Force, Sir John French), the prince did witness some of the horrors of the war.

And while he wasn't fighting on the front, Prince Edward won the respect of the common soldier for wanting to be there.

Edward Likes Married Women. Prince Edward was a very good-looking man. He had blonde hair and blue eyes and a boyish look on his face that lasted his entire life. Yet, for some reason, Prince Edward preferred married women.

In 1918, Prince Edward met Mrs. Winifred ("Freda") Dudley Ward. Despite the fact that they were about the same age (23), Freda had been married for five years when they met. For 16 years, Freda was Prince Edward's mistress.

Edward also had a long-time relationship with Viscountess Thelma Furness. On January 10, 1931, Lady Furness hosted a party at her country house, Burrough Court, where, in addition to Prince Edward, Mrs. Wallis Simpson and her husband Ernest Simpson were invited. It was at this party the two first met.

Prince Edward was soon to be infatuated with Mrs. Simpson; however, she didn't make a big impression on Edward at their first meeting.

Mrs. Wallis Simpson Becomes Edward's Only Mistress. Four months later, Edward and Mrs. Wallis Simpson met again and seven months after that the prince had dinner over at the Simpson's house (staying until 4 a.m.). And though Wallis was a frequent guest of Prince Edward's for the next two years, she was not yet the only woman in Edward's life.

In January 1934, Thelma Furness made a trip to the United States, entrusting Prince Edward to the care of Wallis in her absence. Upon Thelma's return, she found that she was no longer welcome in Prince Edward's life - even her phone calls were refused.

Four months later, Mrs. Dudley Ward was similarly cut out of the prince's life. Mrs. Wallis Simpson was then the prince's single mistress.

Who Was Mrs. Wallis Simpson? Mrs. Wallis Simpson has become an emotional figure in history. Along with this, many descriptions of her personality and motives for being with Edward have caused some extremely negative descriptions; the nicer onces range from witch to seductress. So who really was Mrs. Wallis Simpson? 
Mrs. Wallis Simpson was born Wallis Warfield on June 19, 1896 in Maryland, United States. Though Wallis came from a distinguished family in the United States, in the United Kingdom being an American was not highly regarded. Unfortunately, Wallis's father died when she was only five months old and left no money; thus his widow was forced to live off the charity given to her by her late husband's brother.

As Wallis grew into a young woman, she was not necessarily considered pretty. However, Wallis had a sense of style and pose that made her distinguished and attractive. She had radiant eyes, good complexion and fine, smooth black hair which she kept parted down the middle for most of her life.

Wallis' First and Second Marriages. On November 8, 1916 Wallis Warfield married Lieutenant Earl Winfield ("Win") Spencer, a pilot for the U.S. Navy. The marriage was reasonably good until the end of World War I, as it was with many exsoldiers who became bitter at the inconclusiveness of the war and had difficulty adapting back to civilian life.

After the armistice, Win began to drink heavily and also became abusive.

Wallis eventually left Win and lived six years by herself in Washington. Win and Wallis weren't yet divorced and when Win begged her to rejoin him, this time in China where he had been posted in 1922, she went.

Things seemed to be working out until Win started drinking again. This time Wallis left him for good and sued for a divorce, which was granted in December 1927.

In July 1928, only six months after her divorce, Wallis married Ernest Simpson, who worked in the family shipping business. After their marriage, they settled down in London. It was with her second husband that Wallis was invited to social parties and invited to Lady Furness's house where she first met Prince Edward.

Who Seduced Whom? While many blame Mrs. Wallis Simpson for seducing the prince, it seems rather more likely that she was herself seduced by the glamor and power of being close to the heir of Britain's throne.

At first, Wallis was just glad to have become included in the prince's circle of friends. According to Wallis, it was in August 1934 that their relationship became more serious. During that month, the prince took a cruise on Lord Moyne's yacht, the Rosaura. Although both Simpsons were invited, Ernest Simpson could not accompany his wife on the cruise because of a business trip to the United States.

It was on this cruise, Wallis stated, that she and the prince "crossed the line that marks the indefinable boundary between friendship and love." [15, p. 79].

Prince Edward became increasingly infatuated with Wallis. But did Wallis love Edward? Again, many people have said that she did not and that she was a calculating woman who either wanted to be queen or who wanted money. It seems more probable that while she was not infatuated with Edward, she loved him.

Edward Becomes King. At five minutes to midnight on January 20, 1936, King George V, Edward's father, passed away. Upon King George V's death, Prince Edward became King Edward VIII.

To many, Edward's grief over his father's death seemed much greater than the grieving of his mother or his siblings. Though death affects people differently, Edward's grief might have been greater for his father's death also signified his acquisition of the throne, complete with the responsibilities and eminence that he deplored.

King Edward VIII didn't win many supporters at the beginning of his reign. His first 
act as the new king was to order the Sandringham clocks (See APPENDIX A), which were always a half an hour fast, set to the correct time. This symbolized to many a king who rejected his father's work.

Still, the government and the people of Great Britain had high hopes for King Edward. He had seen war, traveled the world, been to every part of the British empire, seemed sincerely interested in social problems, and had a good memory. So what went wrong?

Many things. First, Edward wanted to change many of the rules and become a modern monarch. Unfortunately, this caused Edward to distrust many of his advisors because he saw them as symbols and perpetuators of the old order. He dismissed many of them.

Also, in an effort to reform and curb monetary excesses, he cut the salaries of many royal staff employees to an extreme degree. Employees became unhappy.

The king also began to be late or cancel appointments and events at the last minute. State papers that were sent to him were not protected, some statesmen worried that German spies had access to these papers. At first these papers were returned promptly, but soon it would be weeks before they were returned, some of which had obviously not even been looked at.

Wallis Distracted the King. One of the main reasons he was late or canceled events was because of Mrs. Wallis Simpson. His infatuation with her had grown so extreme that he was severely distracted from his State duties. Some thought she might be a German spy handing State papers over to the German government.

The relationship between King Edward and Mrs. Wallis Simpson came to an impasse when the king received a letter from Alexander Hardinge, the king's private secretary, that warned him that the press would not remain silent much longer and that the government might resign if this continued.

King Edward was faced with three options: give up Wallis, keep Wallis and government would resign, or abdicate and give up the throne. Since King Edward had decided that he wanted to marry Mrs. Wallis Simpson (in his autobiography he wrote that he had decided to marry her as early as 1934), he had little choice but to abdicate [16, p. 277].

King Edward VIII Abdicates. Whatever her original motives, until the end, Mrs. Wallis Simpson didn't mean for the king to abdicate. Yet the day soon came when King Edward VIII was to sign the papers that would end his rule.

At 10 a.m. on December 10, 1936, King Edward VIII, surrounded by his three surviving brothers, signed the six copies of the Instrument of Abdication [8].

On December 10, 1936, King Edward VIII submitted his abdication and it was endorsed by Parliament the next day. He thus became the only British monarch ever to resign voluntarily. On December 11th, Edward VIII publicly announced his decision via radio to a worldwide audience [11].

The Duke and Duchess of Windsor. At the moment of King Edward VIII's abdication, his brother Albert, the next in line for the throne, became King George VI (Albert was the father of Queen Elizabeth II).

On the same day as the abdication, King George VI bestowed upon Edward the family name of Windsor. Thus, Edward became the Duke of Windsor and when he married, Wallis became the Duchess of Windsor. 
Mrs. Wallis Simpson sued for a divorce from Ernest Simpson, which was granted, and Wallis and Edward married in a small ceremony on June 3, 1937.

To Edward's great sorrow, he received a letter on the eve of his wedding from King George VI stating that by abdicating, Edward was no longer entitled to the tile "Royal Highness". But, out of generosity for Edward, King George was going to allow Edward the right to hold that title, but not his wife or any children. This greatly pained Edward for the rest of his life, for it was a slight to his new wife.

After the abdication, the Duke and Duchess were exiled from Great Britain. Although a number of years had not been established for the exile, many believed it would only last a few years; instead, it lasted their entire lives.

Royal family members shunned the couple. The Duke and Duchess lived out most of their lives in France with the exception of a short term in the Bahamas as governor.

Edward passed away on May 28, 1972, a month shy of his 78th birthday. Wallis lived for 14 more years, many of which were spent in bed, secluded from the world. She passed away on April 24, 1986, two months shy of 90.

На основному етапі викладач перевіряє засвоєння нового лексичного матеріалу.

І. Завдання для перевірки опанування нової лексики.

1. While studying the case pay attention to the underline words. If you don't know their meaning consult the dictionary.

2. Using the case write down the words and word-combinations with the meaning "to be in love", "one's girlfriend/boyfriend", "to court".

3. Using the Internet sources, write down the idioms connected with the notion "love". Represent them in class.

4. Study the following idioms $[4 ; 12 ; 13]$ (див. табл. 1). Try to guess their meaning. Connect the following idioms with their meaning.

Таблиця 1

Idioms about love

\begin{tabular}{|c|l|l|}
\hline № & \multicolumn{1}{|c|}{ Idioms } & \multicolumn{1}{|c|}{ Lexical meaning } \\
\hline 1. & love at first sight & a. a couple who get along perfectly \\
\hline 2. & to fancy someone (B. E.) & b. find the right or perfect person \\
\hline 3. & to have a crush on someone & c. for a couple to show everyone how much they are in love \\
\hline 4. & to go out with someone (B. E.) & d. get married \\
\hline 5. & to fall head over heels for someone & e. get married \\
\hline 6. & to be loved-up (B. E.) & f. instant love \\
\hline 7. & find Mr. Right & g. the place where two lovers live \\
\hline 8. & to be lovey-dovey & h. the words "I love you" \\
\hline 9. & those three little words & i. to be able to think only about one person \\
\hline 10. & a love-nest & j. to completely fall in love \\
\hline 11. & a match made in heaven & k. to date someone \\
\hline 12. & walk down the aisle together & l. to exist in a warm feeling of love \\
\hline 13. & tie the knot & m. to find someone attractive \\
\hline
\end{tabular}

Особлива увага під час роботи над кейсом приділяється виконанню таких творчих завдань:

1. Make up a short story using the underline words from the case and the given 
idioms about the first dates of Edward VIII and Mrs. Wallis Simpson: to have a crush on someone, to be loved-up, find Mr. Right, to be lovey-dovey, those three little words, a match made in heaven.

2. Imagine that you are Edward VIII. Write the Valentine card (or a letter on the Valentine's Day) on his behalf to Mrs. Wallis Simpson using the following idioms and proverbs: "beauty is in the eye of the beholder (beauty is subjective), let your heart rule your head (allow your emotions to control your rational side), wear your heart on your sleeve (show other people how you are feeling)".

II. Для поглибленої роботи та подальшого обговорення кейсу "Love or Duty, that is a question..." студентам пропонується така система запитань і завдань:

1. What kind of person was Edward VIII as a teenage and a young man? Was he growing up with the understanding that he is a future King of the UK?

2. Watch the part of the film "The King's Speech". How was Edward VIII described in that scene of his father's death? What did he feel immediately after his father's death?

3. Edward VIII was on the throne for 11 months. Did he demonstrate an interest in ruling the country? What or who distracted him? What was his life drama?

4. Edward's VIII first act as the new king was to order the Sandringham clock [14] set to the correct time. What did the Sandringham clock symbolize? Why did he change that tradition?

5. Was the abdication the hard choice for Edward VIII? That was he thinking about on the eve of signing the Instrument of Abdication (December 10, 1936)? Described this evening.

6 . Think about the book he might be reading on the eve of signing the Instrument of Abdication. Explain your choice.

7. Listen to Edward's VIII public speech about his decision to a worldwide audience [11]. How did Edward VIII explain his choice? Quote his words.

8. Do you agree with Edward's VIII decision? Did he have the right to do in such a way?

9. What is your attitude towards Edward's VIII abdication? Explain your ideas.

На заключному етапі за підсумками групового обговорення проблеми "Love or Duty, that is a question..." студентам можна запропонувати написати лист або есе на такі теми:

- Write a letter to Edward VIII summing up your ideas about the kind's choice.

- Write an essay "The story is about a prince who didn't wanted to be a king".

Висновок. Завдяки використанню кейс-технології на практичному занятті 3 англійської мови студенти поглибили лексичний запас за темою "Love and Romance", набули вмінь застосовувати нову лексику у процесі монологічного та діалогічного спілкування, відпрацювали вміння висловлювати власні думки іноземною мовою, вдосконалили граматичні навички застосування Past Tenses та Conditional Sentences в нових ситуаціях спілкування. Крім того, вони розвинули вміння з аудіювання, навчилися виокремлювати з мовленнєвого потоку необхідну інфрормацію, поглибили комунікативну культуру спілкування.

Звернення до кейс-технології дало змогу забезпечити міждисциплінарні зв'язки “англійська мова - історія, література, лінгвокультурознавство", розвинути дослідницькі і творчі вміння, підвищити мотивацію до поглибленого вивчення дисципліни; активізувати навчально-пізнавальну діяльність студентів. 


\section{Використана література:}

1. Вітченко А. О., Осьодло В. І., Салкуцан С. М. Технології навчання у вищій військовій школі: теорія і практика : навч.-метод. посіб. / за заг. ред. професора В. М. Телелима. Київ : НУОУ ім. Івана Черняховського, 2016. 250 с.

2. Пометун О. І. Інтерактивні технології навчання / О. І. Пометун, Л. В. Пироженко, Г. І. Коберник та ін. Київ : Наук. світ, 2004. 85 с.

3. Сисоєва С. О. Інтерактивні технології навчання дорослих : навч.-метод. посіб. Київ : ВД “ЕКМО”, $2011.320 \mathrm{c}$.

4. 25 Fantastic Idioms about Love and their Meanings [Електронній ресурс]. Режим доступу: https://www.myenglishteacher.eu/blog/20-suprisingly-funny-idioms-about-love/. Назва з екрану.

5. Bloch Michael. Wallis \& Edward: Letters 1931-1937. London : Weidenfeld \& Nicolson, 1986. 320 p.

6. Edward VIII [Електронній ресурc]. Режим доступу : https://www.encyclopedia.com/people/history /british-and-irish-history-biographies/edward-viii. Назва з екрану.

7. Edward VIII abdicates [Електронній ресурс]. Режим доступу : https://www.history.com/this-day-inhistory/edward-viii-abdicates. Назва з екрану.

8. Edward VIII abdication crisis [Електронній ресурс]. Режим доступу: https://en.wikipedia.org/wiki /Edward_VIII_abdication_crisis. - Назва з екрану.

9. Inside the Biggest Royal Scandal Ever: How King Edward VIII's Explosive Affair with Wallis Simpson Changed the Couse of History [Електронній ресурс]. Режим доступу : http://www.eonline.com/news 1900012/inside-the-biggest-royal-scandal-ever-how-king-edward-viii-s-explosive-affair-with-wallis-simpsonchanged-the-course-of-history. - Назва з екрану.

10. King Edward VIII Abdicated for Love [Електронній ресурс]. Режим доступу : https://www.thoughtco.com/king-edward-viii-abdicated-for-love-1779284. Назва з екрану.

11. King Edward VIII Abdication Speech 1936 [Електронній ресурс]. Режим доступу : https://www.youtube.com/watch?v=re6G1hTlrEo. - Назва з екрану.

12. Love and Relationship Idioms [Електронній ресурс]. Режим доступу: http://www.idiomconnection.com/relationship.html. - Назва з екрану.

13. Love Idioms [Електронній ресурс]. Режим доступу : https://www.theidioms.com/love/. Назва 3 екрану.

14. Sandringham Time [Електронній ресурс]. Режим доступу: https://www.historic-uk.com/CultureUK /Sandringham-Time/. - Назва з екрану.

15. Warwick Christopher. Abdication. London : Sidgwick \& Jackson, 1986. 176 p.

16. Ziegler Paul. King Edward VIII: The Official Biography. London : Collins, 1990. 654 p.

\section{References:}

[1] Pometun O. I. (2004). Interaktyvni texnologiyi navchannya / O. I. Pometun, L. V. Pyrozhenko, G. I. Kobernyk ta in. K. : Nauk. svit. $85 \mathrm{~s}$.

[2] Sysoyeva S. O. (2011). Interaktyvni texnologiyi navchannya doroslyx : navch.-metod. posib. Kyiv : VD "EKMO". $320 \mathrm{~s}$.

[3] Vitchenko A. O., Osodlo V. I., Salkuczan S. M. (2016). Texnologiyi navchannya u vyshhij vijs kovij shkoli : teoriya i praktyka : navch.-metod. posib. / za zag. red. profesora V. M. Telelyma. Kyiv : NUOU im. Ivana Chernyaxovskogo. $250 \mathrm{~s}$.

[4] 25 Fantastic Idioms about Love and their Meanings [Elektronnii resurs]. Rezhym dostupu : https://www.myenglishteacher.eu/blog/20-suprisingly-funny-idioms-about-love/. Nazva z ekranu.

[5] Bloch Michael. (1986). Wallis \& Edward: Letters 1931-1937. London : Weidenfeld \& Nicolson. - 320 p.

[6] Edward VIII [Elektronnii resurs]. Rezhym dostupu: https://www.encyclopedia.com/people/history /british-and-irish-history-biographies/edward-viii. Nazva z ekranu.

[7] Edward VIII abdicates [Elektronnii resurs]. Rezhym dostupu : https://www.history.com/this-day-inhistory/edward-viii-abdicates. Nazva z ekranu.

[8] Edward VIII abdication crisis [Elektronnii resurs]. Rezhym dostupu: https://en.wikipedia.org /wiki/Edward_VIII_abdication_crisis. Nazva z ekranu.

[9] Inside the Biggest Royal Scandal Ever: How King Edward VIII's Explosive Affair with Wallis Simpson Changed the Couse of History [Elektronnii resurs]. Rezhym dostupu : http://www.eonline.com/news 
/900012/inside-the-biggest-royal-scandal-ever-how-king-edward-viii-s-explosive-affair-with-wallissimpson-changed-the-course-of-history. Nazva z ekranu.

[10] King Edward VIII Abdicated for Love [Elektronnii resurs]. Rezhym dostupu : https://www.thoughtco.com/king-edward-viii-abdicated-for-love-1779284. Nazva z ekranu.

[11] King Edward VIII Abdication Speech 1936 [Elektronnii resurs]. Rezhym dostupu : https://www.youtube.com/watch?v=re6G1hTlrEo. Nazva z ekranu.

[12] Love and Relationship Idioms [Elektronnii resurs]. Rezhym dostupu : http://www.idiomconnection.com /relationship.html. - Nazva z ekranu.

[13] Love Idioms [Elektronnii resurs]. Rezhym dostupu : https://www.theidioms.com/love/. Nazva z ekranu.

[14] Sandringham Time [Elektronnii resurs]. Rezhym dostupu : https://www.historic-uk.com /CultureUK/Sandringham-Time/. Nazva z ekranu.

[15] Warwick Christopher. (1986). Abdication. London : Sidgwick \& Jackson. - 176 p.

[16] Ziegler Paul. (1990). King Edward VIII: The Official Biography. London : Collins. 654 p.

ВИТЧЕНко А. Ю. Использование кейс-технологии на практических занятиях по английскому языку в учреждениях высшего образования.

Среди основных методических проблем преподавания английского языка в заведениях высшего образования большое значение имеет использование интерактивных технологий, которые обеспечивают реализачию коммуникативного подхода, содействуют формированию иноязычной компетентности. $K$ наиболее эффективным интерактивным технологиям обучения принадлежит кейс-технология, которая дает возможность активизировать прочесс иноязычной коммуникации, проблематизировать учебный материал, сформировать у студентов опыт практического использования приобретенных знаний, умений и навычек во время изучения иностранного языка.

В статье теоретически обоснована и практически проверена эффективность использования кейс-технологии на практических занятиях по английскому языку в высших учебных заведениях. Раскрыта сущность кейс-технологии, которая состоит в изучении конкретных случаев (ситуаций, историй, тексты которых называются “кейсами”) из жизни и профессиональной деятельности для общего анализа, обсуюдения и формирования решений. Проанализированы преимущества использования кейсов на практических занятиях по английскому языку, рассмотрены структурные элементы кейса. Bыделены основные этапь внедрения кейс-технологии, приведен пример использования кейс-технологии на практических занятиях по английскому языку в высших учебных заведениях.

Доказано, что использование кейс-технологии позволяет актуализировать лексику в проиессе анализа и обсуждения предлагаемых проблемных ситуаций, отрабатывать практические умения строить монологические высказывания, участвовать в диалогах та дискуссиях по теме кейса, повышать интерес к изучению иностранного языка путем проблематизации учебного материала.

Ключевые слова: кейс, кейс-технология, структурные элементы кейса, основные этапь внедрения кейс-технологии, практические занятия по английскому языку, высшие учебные заведения.

VITCHENKO A. Use case technology on practical English classes in institutions of higher education.

Among the main methodological problems of teaching English in higher education institutions, the use of interactive technologies that provide a communicative approach and contribute to the formation of foreign language competence is of great importance. The most effective interactive learning technologies include case technology, which makes it possible to activate the process of foreign language communication, to problematize educational material, to form students' experience in the practical use of acquired knowledge, skills and abilities while learning a foreign language.

The article theoretically justified and practically tested the effectiveness of the case-technology use on practical English classes in institutions of higher education. The main ideas of the case- 
technology is revealed, the advantages of using cases on practical English classes are analysed, the structural elements of the case are considered. The main stages of the case-technology introduction in universities, and the example of the case-technology use on practical English classes in institutions of higher education are given.

It is proved that the use of case-technology allows to update the vocabulary in the process of analysing and discussing the proposed problem situations, to develop the practical skills while making up the monologues, to participate in dialogues and discussions on the case topic, to increase interest in learning foreign language through problematization of the educational material.

Keywords: case technology, the advantages of case studies using, the structural elements of a case, the stages of case technology introduction, an example of using case technology on practical English classes in institutions of higher education.

DOI: https://doi.org/10.31392/NZ-npu-143.2019.08

УДК 378.011.3-051:81’243):004

Гладка I. A.

\section{ВПРОВАДЖЕННЯ ІНТЕРАКТИВНИХ ТЕХНОЛОГІЙ У ПРОЦЕСІ ПІДГОТОВКИ ВИКЛАДАЧА АНГЛІЙСЬКОЇ МОВИ}

Сьогодні від нового покоління вимагаються розвинені особистісні якості, які давали б йому змогу креативно підходити до вирішення сучасних проблем $i$ згодом виховувати $і$ навчати нове покоління. У зв'язку з ичим перед викладачем англійської мови постають нові завдання зі створення оптимальних умов для розвитку студентів-філологів та формування майбутнього викладача англійської мови нової формачії.

Статтю присвячено впровадженню інтерактивних технологій у процесі підготовки викладача англійської мови. ХХІ сторіччя відкрило можливості для розвитку новітніх інтерактивних технологій, де вчені розробляють шляхи, як навчити спілкуватися іноземними мовами, зокрема англійською. Мета статті полягає в тому, щэоб запропонувати перевірені інтерактивні технології для використання їх в процесі підготовки викладача англійської мови та створення комфортних умов, за яких студент зможе вільно спілкуватися англійською мовою та довести ефективність ӥх використання.

Інтерактивна діяльність на практичних заняттях з англійської мови передбачає розвиток й організацію спілкування двох $і$ більше осіб, що веде до взаємодії і взаєморозуміння, до спільного рішення значущих для кожного учасника завдань. Домінування однієї думки над іншою не може бути при інтерактиві. Методи з широким спектром можливостей, такі як дискусї, диспути, рольові ігри, характеризуються значною змістовністю, чіткою структурою, більш иілеспрямованою і організованою участю майбутніх викладачів, активністю прояву позицій. Це все й забезпечує комплексний вплив на інтелектуальну, емоиійну $і$ мотиваційну сферу студентів.

Ключові слова: інтерактивна технологія, методи, майбутній викладач, методика, вправи, креативність, інтерактивна діяльність, студент.

Розвиток українського суспільства за останні 28 років характеризується важливими соціально-економічними перетвореннями, коли від нового інтерактивного покоління вимагаються розвинені особистісні якості, які давали б 